\title{
The Development of Civilians Caring about AIDS
}

\author{
$1^{\text {st }}$ Argyo Demartoto* \\ Department of Sociology \\ Universitas Sebelas Maret \\ Surakarta, Indonesia \\ argyodemartoto_fisip@staff.uns.ac.id
}

\author{
$2^{\text {nd }}$ Siti Zunariyah \\ Department of Sociology \\ Universitas Sebelas Maret \\ Surakarta, Indonesia \\ zunariyah@staff.uns.ac.id
}

\author{
$3^{\text {rd }}$ Sri Hilmi Pujihartati \\ Department of Sociology \\ Universitas Sebelas Maret \\ Surakarta, Indonesia \\ srihilmi@staff.uns.ac.id
}

\begin{abstract}
Stigma and discrimination against People Living with HIV/AIDS (PLWHAs) make them lose job, social status, and family's and community's support. This paper aims to study the Civilians Caring about AIDS (CCA) developing process, their acceptance to PLWHAs and active participation in coping with HIV/AIDS in Punggawan, Surakarta Indonesia. Informants of research were PLWHAs, Chairperson of Solo Plus Peer Support Group, CCA of Punggawan, Surakarta, Chairperson of Surakarta Health Office, Program Manager of Surakarta AIDS Commission, Manager of Surakarta Half-way House of Lentera, Voluntary Counseling and Testing Counselor in Punggawan Public Health Center, and relevant document. Techniques of collecting data were observation, indepth interview, and documentation. Data analysis was interactive model of analysis with Elias' Civilizing Process theory. In coping with HIV/AIDS, Punggawan people consider religious value, culture, and society norm; respect human dignity and prestige, and gender equality. The activity focused on maintaining and solidifying family's resilience and wellbeing, was integrated into development program, and conducted systematically and comprehensively to maintain reasonable and productive social-economic life for PLWHAs and people affected with HIV/AIDS. Partnership-based HIV/AIDS management was conducted within society and government, involving active participation of key population, PLWHAs, and people affected with HIV/AIDS. PLWHAs adapt to family and community environment, thereby not encountering discrimination in society life.
\end{abstract}

\section{Keywords-acceptance, AIDS, civilians, participation}

\section{INTRODUCTION}

Indonesia is one of Asian countries with highest HIV/AIDS epidemic growth and out of all people with HIV/AIDS (PLWHAs), 620,000 are adult and 220,000 are female $(35.48 \%)$ [1-3]. Meanwhile, there have been 2,857 HIV/AIDS cases during 2005-2018 in Surakarta, Indonesia, consisting of $974 \mathrm{HIV}, 1,883$ AIDS cases, and 701 deaths.

PLWHAs are associated with stigma and discrimination in the form of excessive prejudice, negative attitude, and mistreatment coming directly from people surrounding $[4,5]$. About 5 (five) millions PLWHAs are expected to encounter high social stigma, so that only $5-10 \%$ are diagnosed and get treatment. The consequence of stigma and discrimination, PLWHAs withdraw from family environment, friendship group, and surrounding community. In addition, they encounter limited healthcare service, limited education, eroded human right protection, and psychological damage. Generally, PLWHAs have limitation in accessing HIV testing, having treatment, and other getting other HIV services [6-8]. Many PLWHAs lose their income, job, family, marriage, life expectancy, and reputation, and they wish to have child and healthcare service [9].
PLWHAs who are losing job, social status, and family's and community's support tend to avoid appropriate treatment, thus more people with HIV are undetected for their progress $[10,11]$. Not only does stigma against PLWHAs make an individual's life more difficult, but it also relates to HIV/AIDS epidemic development globally. This condition is also triggered with unstructured stigma from the government, healthcare provider, and workplace, household, and community environment, and many constraints in society life $[12,13]$.

The factor resulting in stigma against PLWHAs is, among others, living with HIV/AIDS relates to death; unhealthy and unsafe sexual behavior, Injection Drug Users (IDUs) victim, sexual worker, associated with sexual-relation transmissiondue to amoral behavior. The infection is considered as the punishment on the bad deed resulting from no personal responsibility in living within society. The society's misperception on PLWHAs' life risk makes them marginalized from the society life and the limited service needed by PLWHAs. Such the condition contributes to the expansion of HIV epidemic and the increase of death number among AIDS patients globally $[6,14,15]$

Epidemic, stigmatization, and discrimination are the factors indicating individual, family, and society's inability of protecting themselves and responding to the increase of PWHA number. Meanwhile, government has established three-zero measures to cope with HIV/AIDS: zero death due to AIDS, zero HIV transmission, and zero discriminative treatment against PLWHAs [16]. In the context of zero discriminative treatment against PLWHAs, people can participate actively through supporting PLWHAs. It is the reflection of a community's civilization [17, 18]. Civilization is a continuous development process that can be learnt easily. As a civilizing process, civilization is often not more than a technology of a civilized action, and it even tends to be decivilized because the civilizing attempt is often dominative in nature, through violence by one group against another.

Figuration is social process leading to the establishment of inter-individual relation. Figuration is not an external structure and forces inter-individual relation, but it is interrelation itself. Individual is considered as opened and interdependent. Figuration is composed of the individual compilations. Power is important in social figuration and thereby is fluid [19, 20]. Similarly CCA should also be inculcated, developed, and socialized within community. The heart of social figuration that always changes (is fluid) includes the fluctuation of either tense or loose balance, the balance of power changing originally into one side and then into another. The fluctuating power balance is the structural characteristic of individual social figurations' current. Generally, social figuration arises and develops intangibly 
and in unplanned manner. It is called a process of interdependence origin requiring emotional approach uniting both of them [21].

Figuration relates to the assumption that individual is opened to and is interrelated to another. The opened and interdependent actor is desirable to figuration sociology. The more civilized people serve as sociological fact (sociogenesis). There is a change occurring gradually in the community's behavior and psychological structure (footnote) $[19,20]$. In addition, there is a relationship between the change of behavioral structure and psychological structure of community, e.g. etiquette. There is a gradual historical transformation from some types of behavior such as stigmatizing and discriminating PLWHAs into the more civilized ones. In Punggawan Surakarta, some PLWHAs live and are denied by their family, but some others are denied by their community. CCA is established by the community to prevent and to cope with HIV/AIDS, including the existence of PWHA. The objective of research was to study the process of developing Civilians Caring about AIDS, so that people can accept PLWHAs and participate actively in coping with HIV/AIDS in Punggawan, Surakarta Indonesia.

\section{METHOD}

This research took place in Punggawan, Surakarta Indonesia because Citizens Caring about AIDS has been established and participated actively in the activity of coping with HIV/AIDS. This descriptive qualitative research presents detailed description about Punggawan people that can accept PLWHAs, coming from either their family or people surrounding, and participate actively in promotive, preventive, curative, and rehabilitative activities related to HIV/AIDS management [22].

Primary data was obtained directly from PLWHAs living in Punggawan (A1, A2, and A3), Chairperson of Solo Plus Peer Support Group (B), Citizens Caring about AIDS in Punggawan Surakarta (C1 and C2), Chairperson of Surakarta Health Office (D), Program Manager of Surakarta AIDS Commission (E), Manager of Surakarta Halfway House of Lentera (F), Counselor of Voluntary Counseling and Testing in Puskesmas Punggawan $(\mathrm{G})$ by conducting interview and observation on the research object. In addition, secondary was obtained from related document such as Report on HIV/AIDS Situation and Conditionin Punggawan and Surakarta [23]. To validate the data, source and method triangulations were used. Data analysis was conducted continuously from the beginning to the end of research by distinguishing the objective notes from the reflective ones, and thereby research objectivity was obtained.

\section{RESULT AND DISCUSSION}

C1 and C2 stated that Punggawan people respect the principles of HIV/AIDS management. Those principles are paying attention to religious values, culture, and societal norms; respecting human dignity and prestige, and paying attention to justice and gender equality; the activity is directed to maintain and to solidify family resilience and welfare; the activity is integrated into development program at regency/city and local levels. $\mathrm{C} 1$ added that Punggawan people conduct promotive, preventive, curative and rehabilitative activities systematically and in integrated manner, from improving healthy life behavior, disease prevention, medication, and treatment, to supporting PLWHAs and people affected with HIV/AIDS. This activity is held by people, and Kelurahan and local government based on partnership scheme.

CCA or human resource involved in HIV/AIDS management in Punggawan consists of health and non-health workers. It is confirmed by A1, A2, A3, F and G. Health workers are professionals with competency and authority in medical area, e.g. G. Non-health workers contribute to policy, welfare, health, education, social and cultural areas including all HIV/AIDS problems holistically, e.g. C1, C2, and $\mathrm{E}$. In addition, it involves the active participation of key populations including PLWHAs such as $\mathrm{C} 1$ and $\mathrm{C} 2$ and those affected with HIV/AIDS. CCA supports PLWHAs and people affected with HIV/AIDS in order to maintain the feasible and productive social-economic life.

The process of adjusting different elements in society's life can be called social integration, as it produces society life pattern with harmonious functions. There are two basic elements of social integration: firstly, adjustment and secondly functional. If social diversity fails to achieve the adjustment between one and another, social disintegration will occur. In this case, social diversity fails to create social harmony of society (dysfunctional) [24-27]. D and E said that PLWHAs' social integration in society life is their adaptation to family and community environment, thereby not encountering discrimination in living within society.

B suggested that social support can be given to PLWHAs through 2 (two) integrated activities involving stakeholders' intervention and behavioral changing intervention [28]. The improvement of stakeholders' role is intended to create social order in the conducive key-population environment, while the behavioral changing intervention is intended to give understanding and to change the group's behavior collectively and the behavior of each individual in group, thereby reducing discrimination against PLWHAs. HIV/AIDS treatment and support can be implemented with the approach option needed, e.g. healthcare facility-based treatment and Community Home Based Care. E said that HIV/AIDS treatment and support should be conducted holistically and comprehensively with biopsychosocial spiritual approach involving symptom management; acute treatment management; chronic disease management; complication and opportunistic infection prevention; palliative treatment; mental health psychological support, social-economic support, and community empowerment to build support groups; and result evaluation and reporting.

$\mathrm{B}$ added that Community Home Based Care is the form of treatment given to PLWHAs without opportunistic infection preferring home-based treatment. Home-based care treatment aims to prevent infection, to reduce complication, to reduce pain/discomfort, to improve self-acceptance to situation and to understand diagnosis, prognosis and treatment, and to improve independence to achieve highquality life.

The development of civilians caring about AIDS in Punggawan is conducted through an attempt of preventing stigma and discrimination, and of improving PLWHAs' participation, healthy behavior, and family resilience. B thought that the attempt of preventing discriminative behavior can be taken by giving appropriate and complete 
understanding on HIV transmission method and its prevention; empowering people infected with HIV just like other members of society; and inviting all members of society to treat people with HIV non-discriminatively in healthcare service, education, occupation, and all aspects of life. CCA is just like a new figure that can present interdependency by means of benefiting mutually the local people and PLWHAs. Social figuration indicates social process by which opened attitude and behavior are created among members of society and respect grows among public and PLWHAs. Communication, information, and education on HIV/AIDS enable the community to have knowledge, attitude, and behavior caring about AIDS, and respecting PLWHAs [19, 20]. It is socialized in family, school, workplace and public.

C2 stated that everyone should participate actively in preventing and coping with HIV epidemic corresponding tohisown ability and role. People can participate in the attempt of coping with HIV/AIDS by means of promoting health life behavior, improving family resilience, preventing stigma and discrimination against people infected with HIV and their family, and against key population community, creating and developing CCA and supporting the most at risk population (MRAPs) to be infected with HIV to have them examinedin Voluntary Counseling and Testing (VCT). CCA management and development are further desirable and very relevant to giving the PLWHAs social support.CCA is the organization accommodating public participation in coping with HIV/AIDS and can be established at sub district, kelurahan/village, hamlet/kampong, RW (citizens associations) and RT (neighborhood associations). CCA activity can be integrated into local alert village/citizen association activity.

\section{CONCLUSION}

CCA can accept PLWHAs and participates actively in coping with HIV/AIDS. Civilization is social-psychological behavior represented through HIV/AIDS management program and activity, and serves as civilized one all at once conducted comprehensively and sustainably.

\section{ACKNOWLEDGMENT}

This work was supported by grants from the Ministry of Research, Technology and Higher Education, Indonesia Number: 719 / UN27.71 / PN / 2019.

\section{REFERENCES}

[1] UNAIDS. "Global HIV Statistics. UNAIDS". Switzerland, 2019. Available https://www.unaids.org/sites/default/files/media_asset/UNAIDS_Fac tSheet_en.pdf. (Accessed: February 10, 2020).

[2] Kementerian Kesehatan Republik Indonesia. "Laporan situasi perkembangan HIV dan AIDS di Indonesia sampai dengan Desember 2018". Jakarta: Kementerian Kesehatan Republik Indonesia, 2019.

[3] The Foundation for AIDS Research (amfAR). "Statistics: Women and HIV/AIDS", 2019. Available at: https://www.amfar.org/abouthiv-and-aids/facts-and-stats/statistics--women-and-hiv-aids/. (Accessed: February 10, 2020)

[4] R. Jonsen, and J. Stryker, Editors. "The Social Impact of AIDS In The United States: National Research Council (US) Panel on
Monitoring the Social Impact of the AIDS Epidemic". Washington (DC): National Academies Press (US), 1993.

[5] S. N. Halpin, C.C.M. Lin Ge, D.,Gustafson, K.R.,Robertson, L.H. Rubin, A. Sharma, et al. "Psychosocial Resources and Emotions in Women Living With HIV Who Have Cognitive Impairment: Applying the Socio-Emotional Adaptation Theory." Research and Theory for Nursing Practice, no. 34, vol. 1, pp. 49-64, 2020.

[6] L. Garrett, "The lessons of HIV/AIDS." Foreign Affairs, no. 84, vol. $51,2005$.

[7] Committee on Envisioning a Strategy for the Long-Term Burden of HIV/AIDS: African Needs and US Interests, and Institute of Medicine. "Preparing for the future of HIV/AIDS in Africa: a shared responsibility". National Academies Press, 2011.

[8] S.E. Barkan, "Health, illness, and society: An introduction to medical sociology". Rowman \& Littlefield Publishers, 2020.

[9] Stangl, B. Brady, and K. Fritz. "Technical brief: measuring HIV stigma and discrimination”. Washington, DC: International Center for Research on Women, 2012.

[10] UNAIDS and WHO. "Guidance on Ethics and Equitable Access to HIV Treatment and Care". Geneva, Switzerland: UNAIDS and WHO, 2004

[11] Machado. "Women and HIV and AIDS: Gendered Dimensions of Care: Confronting the Crisis." Social Work Review, vol. 51. no. 1, 2020.

[12] J.R. Herbold, "AIDS policy development within the Department of Defense." Military medicine, no.151, vol. 12, pp. 623-627, 1986.

[13] T.S. Betancourt, M.K.S. Fawzi, C. Bruderlein, C. Desmond, and J.Y. Kim. "Children affected by HIV/AIDS: SAFE, a model for promoting their security, health, and development." Psychology, Health \& Medicine, no. 15, vol. 3, pp. 243-265, 2010.

[14] M.Y. Smith, J., Egert, G. Winkel, and J. Jacobson. "The impact of PTSD on pain experience in persons with HIV/AIDS." Pain, vol. 98, issue 1-2, pp. 9-17, 2002.

[15] K. Collica. "Female prisoners, AIDS, and peer programs: How female offenders transform their lives". Springer Science \& Business Media, 2012.

[16] Haghdoost and M.Karamouzian. "Zero new HIV infections, zero discrimination, and zero AIDS-related deaths: feasible goals or ambitious visions on the occasion of the world AIDS day?". International journal of preventive medicine, no.3, vol. 12, p. 819, 2012.

[17] M. Heijnders and S. Van Der Meij. "The fight against stigma: an overview of stigma-reduction strategies and interventions". Psychology, Health and Medicine, no. 11, vol. 3, pp.353-363, 2006.

[18] Stangl, V. Go, C. Zelaya, L. Brady, L. Nyblade and L. StackpoolMoore. "Enabling the scale-up of efforts to reduce HIV stigma and discrimination: a new framework to inform program implementation and measurement". In Poster presented at: XVIII International AIDS Conference, 2010.

[19] N. Elias. "The Civilizing Process: The History of Manners". London: Blackwell, 1939.

[20] N. Elias. "The Civilizing Process: State Formation and Civilization". London: Blackwell, 1982.

[21] N. Elias, J. Goudsblom, and S. Mennell. "The Norbert Elias Reader: A Biographical Selection”. Oxford: Blackwell Publishers, 1998.

[22] R.R. Mayer and E. Greenwood "The design of social policy research". Prentice Hall, 1980.

[23] C.S. Keller, A. Gonzalez and K.J. Fleuriet "Retention of minority participants in clinical research studies". Western Journal of Nursing Research, no. 27, vol. 3, 1980.

[24] L.F. Berkman and T. Glass. "Social integration, social networks, social support, and health". Social epidemiology, 1, pp. 137-173, 2000.

[25] J. Ramirez-Valles, L. M. Kuhns, R. T.Campbell and R. M. Diaz. "Social integration and health: Community involvement, stigmatized identities, and sexual risk in Latino sexual minorities. Journal of Health and Social Behavior, no. 51, vol. 1, 30-47, 2010.

[26] K. Ford, A. Chamratrithirong, K. Apipornchaisakul, P. Panichapak, and T. Pinyosinwat." Social integration, AIDS knowledge and factors related to HIV prevention among migrant workers in Thailand". AIDS and behavior, no.18, vol. 2, pp. 390-397, 2014. 
[27] L. M. Bogart, J. K. Matovu, G. J. Wagner, H. D. Green, E.D. Storholm, D.J. Klein and A. Kambugu. "A Pilot Test of Game Changers, a Social Network Intervention to Empower People with HIV to be Prevention Advocates in Uganda". AIDS and Behavior, pp. 1-19, 2020.

[28] E. W. Schrimshaw. "Social Support, Conflict, and Integration among Women Living With HIV/AIDS". Journal of Applied Social Psychology, no. 32, vol. 10, pp. 2022-2042, 2002. 